\title{
A case of a prolactinoma resistant to dopamine agonists
}

\author{
Irene Vourliotaki ${ }^{1}$, Ingrid Elizabeth Bonapart ${ }^{1}$, Catherine Stamataki ${ }^{1}$, \\ Eva-Maria Tsapakis ${ }^{2}$, Catherine Saridaki ${ }^{1}$ \\ ${ }^{1}$ Department of Endocrinology and Metabolism, Venizelio General Hospital, Iraklion, Crete, Greece, \\ ${ }^{2}$ Institute of Psychiatry, London, UK
}

\begin{abstract}
ABSTACT
Dopamine agonists are the drugs of choice in the treatment of prolactinomas, the most common type of pituitary adenomas. However, up to $25 \%$ of prolactinomas do not respond to these drugs and alternative treatments have to be considered. We describe a 37-year old female with a microprolactinoma who, although having received all available formulations of dopamine agonists over a period of 11 years, did not respond either clinically-diminution of galactorrhea and restoration of her menstrual cycle - or hormonally through normalisation of the elevated prolactin levels. Throughout the same period, the size of the adenoma remained unchanged. While on high doses of dopamine agonists, the patient presented with side effects such as nausea, vomiting, orthostatic hypotension and tachycardia without any symptoms of psychosis. Therefore, either the dose of the dopamine agonists was not toxic enough for the mesolimbic dopaminergic pathway to be activated or the patient was dopamine-resistant in this pathway as well.
\end{abstract}

Key words: Dopamine agonists, Prolactinoma

\section{INTRODUCTION}

Dopamine agonists are usually effective in the treatment of prolactinomas, which represent the most common type of pituitary adenomas. By and large, these drugs result in normalisation of prolactin (PRL) levels as well as in a substantial reduction in tumour size. ${ }^{1,2}$ Some prolactinomas, however, do not respond to dopamine agonists and are consid-

\footnotetext{
Address correspondence and requests for reprints to: Irene Vourliotaki, Department of Endocrinology and Metabolism, Venizelio General Hospital, Iraklion, Crete, Greece, Tel.: 0030 2810360739, 00302810368206 , Fax: 0030 2810368205, email ivourliotaki@yahoo.gr Received 17-05-05, Revised 24-06-05, Accepted 10-07-05
}

ered to be resistant to this form of treatment. Resistance to dopamine agonists is defined as failure to normalise or reduce PRL levels or tumour size by $\geq 50 \%$. We here present a patient with a prolactinoma resistant to all available dopamine agonist formulations.

\section{PATIENT'S DESCRIPTION}

A 37-year old woman, mother of two children, was referred to the Endocrinology Unit with a history of a microprolactinoma diagnosed 11 years earlier and 2 years following the birth of her second child. At the time, she presented with persistent galactorrhea and secondary amenorrhea. There was 
no history of menstrual disorders prior to her second pregnancy. At the initial diagnosis, her PRL levels were in the range of $150-200 \mathrm{ng} / \mathrm{ml}$, and an initial M.R.I. scan of the pituitary revealed a microadenoma located on the left lateral part of the anterior pituitary, measuring $8 \mathrm{~mm}$ at maximum diameter; there was no sellar enlargement or extrasellar extension. All other causes of hyperprolactinaemia were excluded, and there were no symptoms, signs or laboratory evidence of other pituitary hormonal deficiencies. Estradiol was found to be low normal (125 pmol/L, normal range 0.01-587), with normal gonadotropins and androgens. Personal and family history was unremarkable.

The patient was initially treated with dopamine agonists as follows: During the first four years of her illness, she was given a gradually increasing dose of bromocryptine up to a maximum of $15 \mathrm{mg}$ per day. Usual doses for the treatment of prolactinomas range between 2.5 and $10 \mathrm{mg}$ per day, and for Parkinson's disease maximum doses may reach 60 mg per day. Over this time, amenorrhea and galactorrhea persisted and PRL plasma levels remained unchanged (150-200 $\mathrm{ng} / \mathrm{ml})$. However, the patient experienced significant side effects from this treatment, including orthostatic hypotension, tachycardia, nausea and vomiting and was consistently depressed. In addition, estradiol measured during the $4^{\text {th }}$ year of treatment was $56 \mathrm{pmol} / \mathrm{L}$ (normal range $0.01-587 \mathrm{pmol} / \mathrm{L}$ ), a value lower than the one obtained 4 years previously, whereas serum androgen levels were still normal. Luteinizing Hormone $(\mathrm{LH})$ was low-normal (1.09 IU/L, normal range 1.1-11.6 IU/L) while Follicular Stimulating Hormone (FSH) was normal (9.29 IU/L, normal range 2.8-11.3 IU/ L). No other pituitary hormones abnormalities were noted. On account of the side effects and lack of clinical and biochemical improvement by the end of the $4^{\text {th }}$ year from diagnosis, the patient was switched to quinagolide, another second-line dopamine agonist, gradually reaching a maximum dose of $750 \mu \mathrm{g}$ per day (usual dose for prolactinomas 75-150 $\mu \mathrm{g}$ per day. Quinagolide was better tolerated, but it also failed to reduce the elevated PRL levels. Two years later she was prescribed cabergoline up to $2.5 \mathrm{mg} / \mathrm{d}$ (usual dose for prolactinomas $0.5-1.0 \mathrm{mg}$ weekly). PRL levels before cabergoline administration were
$185 \mathrm{ng} / \mathrm{ml}$. Upon referral to our Unit, the patient had been on cabergoline $2.5 \mathrm{mg} / \mathrm{d}$ for the previous seven months. She complained of occasional nausea and dizziness, symptoms that were however milder by comparison with the side effects she had experienced whilst on bromocryptine.

Except for the various dopamine agonists, the patient did not receive any other medication. The patient's compliance was confirmed by her husband.

On admission, physical examination showed induced galactorrhea. No signs of acromegaly or Cushing's syndrome were present. PRL levels, measured twice while the patient was on cabergoline $2.5 \mathrm{mg} /$ day, were 150 and $160 \mathrm{ng} / \mathrm{ml}$, respectively. The rest of the pituitary function was normal. Androgen levels were found to be normal and serum estradiol was low $(27 \mathrm{pmol} / \mathrm{L}$, normal range $0.01-587 \mathrm{pmol} /$ L). Ultrasound of the uterus and ovaries was normal and did not reveal any evidence of polycystic ovaries. Because of the low serum estradiol, we performed a Bone Mass Density measurement which showed osteopenia (T-score - 1,3). Measurement of bone turnover markers in blood and urine were normal, except for D-pyrilinks in the urine, a bone resorption marker, which was elevated. Blood count, erythrocyte sedimentation rate, renal and liver function tests, a chest $\mathrm{x}$-ray, and urine osmolality were all within normal limits. An M.R.I. scan of the pituitary showed a microadenoma on the left lateral wing of the anterior pituitary, measuring $8 \mathrm{~mm}$ in diameter, similar in size to the one previously demonstrated. No sellar enlargement or extrasellar expansion were observed.

The existence of a mixed Growth Hormone (GH) -PRL secreting adenoma was ruled out by an IGF1 level which was within normal limits and an Oral Glucose Tolerance Test (OGTT) which suppressed GH sufficiently. In addition, whole body $\mathrm{In}^{111}$ octreotide scan was negative.

We also performed a Growth Hormone Releasing Hormone (GHRH) test to ascertain whether $\mathrm{GH}$ was blunted, but the result was negative (Figure 1). The diagnosis of a probable prolactinoma, resistant to dopamine agonists (bromocryptine, cabergoline, quinagolide), was consequently made. Based on the knowledge that dopamine resistance may sometimes 


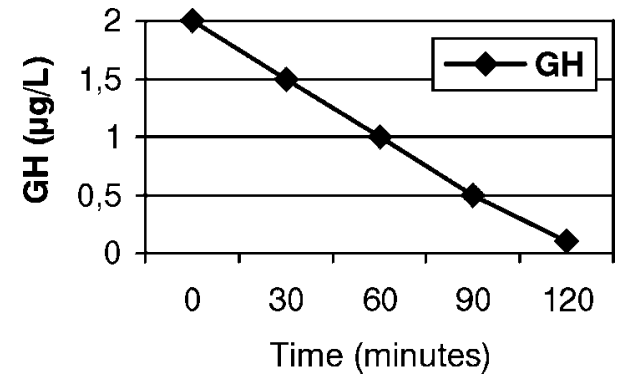

Figure 1. OGTT test for GH.

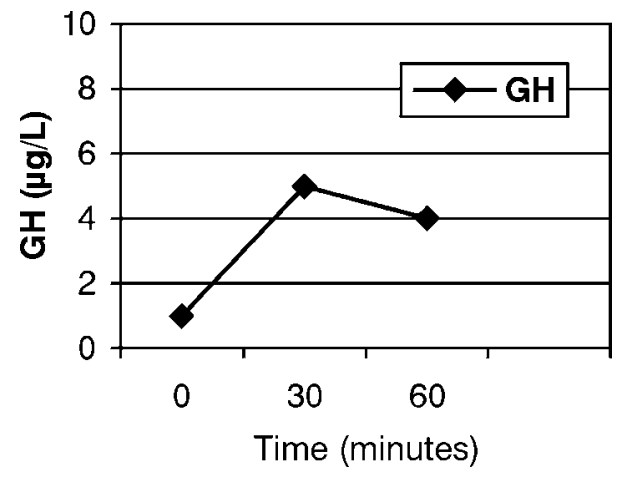

Figure 2. GHRH test for GH.

influence the action of only some dopamine agonists, the patient was prescribed lysuride, a mixed $\mathrm{D}_{2}$ agonist and $\mathrm{D}_{1}$ antagonist ${ }^{3,4}$, which was the only dopamine agonist on the Greek market that she had not been given. One month after lisuride initiation and on a gradually increasing regimen up to a maximum of $1 \mathrm{mg} / \mathrm{d}$ (usual dose for prolactinomas 0.1$0.6 \mathrm{mg} / \mathrm{d}$ ), the patient continued to present galactorrhea, and her PRL levels remained at 160ng/ml.

Radiotherapy, either conventional or focused Gamma-knife, was not recommended in this relatively young patient due to the high possibility of inducing hypopituitarism.

Transsphenoidal excision of the microadenoma was suggested, which she has so far refused.

\section{DISCUSSION}

During treatment with several different dopamine agonists - bromocryptine, quinagolide, cabergoline, lisuride (pergolide is not available in Greece) at maximum or above maximum doses, the patient never achieved reduction in PRL levels and contin- ued to experience amenorrhea and galactorrhea. A thorough work-up revealed no other causes of hyperprolactinaemia besides the microprolactinoma. Over a period of 11 years, PRL levels remained stable as did the size of the adenoma, despite appropriate therapy with dopamine agonists. It is widely known that the growth rate of prolactinomas, especially microprolactinomas (defined as having a maximum diameter $<1 \mathrm{~cm}$ ) is generally slow. ${ }^{1,3}$ Resistant prolactinomas, however, represent the most severe aspect of this entity ${ }^{3}$, have a tendency to grow faster and often result in increasing PRL levels if left untreated for long. This was not the case with our patient.

Dopamine agonist-resistant prolactinomas are characterized by their failure to normalize PRL levels and to decrease tumour size by $\geq 50 \%$ following appropriate treatment. Dopamine agonists act via dopamine $\mathrm{G}$ protein-coupled receptors, of which there are at least 5 subtypes $\left(D_{1-5}\right) . D_{1}$ and $D_{5}$ receptors have a similar structure, are coupled to Gs proteins and stimulate adenylate cyclase, resulting in an increase of intracellular cAMP. $\mathrm{D}_{2}, \mathrm{D}_{3}$ and $\mathrm{D}_{4}$ receptors share a similar structure, are coupled to Gi/o proteins, and their activation inhibits adenylate cyclase, opens potassium and closes calcium channels ${ }^{5}$. The pituitary gland has an abundance of $\mathrm{D}_{2}$ receptors and inhibition of PRL secretion is thought to be mediated through $\mathrm{D}_{2}$ activation.

Positron Emission Tomography (PET) using high affinity dopamine agonists has been used to determine distribution and quantity of dopamine receptors in the brains of rodents and monkeys. ${ }^{6}$ PET has also been used in clinical studies to detect density and affinity of these receptors in human brains in vivo. $^{7}$

Several mechanisms have been suggested to explain the phenomenon of prolactinomas' resistance to dopamine agonists. Work with in vitro cell preparations of resistant prolactin secreting tumours has shown that a decreased number of $\mathrm{D}_{2}$ receptors, due to a lower transcription level of $\mathrm{D}_{2}$ receptor gene, may be responsible for the resistance ${ }^{9-12}$. A reduction of the Gi2 alpha ${ }^{13}$ and $\mathrm{Gi} / \mathrm{o}$ proteins ${ }^{14}$ has also been observed and has been correlated with downregulation of the $\mathrm{D}_{2}$ receptor. 
Additionally, abnormalities in the intracellular GTP/GDP concentrations could be responsible for prolactinomas' resistance to dopamine agonists ${ }^{15}$. Furthermore, the Pit-1 (Pituitary specific) factor, which is a member of the POU (Pit-1, Oct-1/2, Unc89) domain transcription factor family, specific for the anterior pituitary, plays a key role during embryogenesis and specifically in the differentiation and proliferation of somatotrophs, lactotrophs and thyrotrophs. Pit-1 transcripts, identical in size and sequence to those observed in the normal pituitary, have been described in human GH, PRL and Thyroid Stimulating Hormone (TSH) secreting pituitary adenomas. Variable Pit-1 expression has been observed in prolactinomas, depending upon their sensitivity to bromocryptine treatment. A highly significant correlation was found between $\mathrm{D}_{2}$ receptor mRNA and Pit-1 mRNA levels, thus indicating that Pit-1 may either directly or indirectly influence the transcription of the $\mathrm{D}_{2}$ receptor gene ${ }^{16}$.

The brain dopaminergic system consists of four pathways: (a) the mesolimbic pathway; (b) the mesocortical pathway, which participates in functions of learning and memory; (c) the nigrostriatal pathway, which is associated with movement regulation, and forms part of the extrapyramidal system; and (d) the tuberoinfundibular pathway which participates in prolactin regulation, exerting tonic inhibition of PRL secretion ${ }^{17}$.

While on high doses of dopamine agonists, especially bromocryptine, the patient presented with side effects, such as orthostatic hypotension, tachycardia, nausea, vomiting and nervousness. These symptoms are mediated via dopaminergic and adrenergic receptor occupancy both in the central nervous system and the periphery ${ }^{18,19}$. Psychiatric examination of our patient revealed that she did not suffer from psychosis at any stage of her treatment. Psychosis is a well-recognised side effect of treatment with dopamine agonists and is mediated mainly by an action on the mesolimbic pathway of the dopaminergic system ${ }^{20,21}$. It could therefore be arhypothesized that either the dose of dopamine agonists was not high (toxic) enough for the mesolimbic pathway to be activated, or that the patient showed resistance to dopamine in this pathway as well.

Therapeutic approaches to dopamine resistant prolactinomas include: a switch to another type of dopamine agonist, transphenoidal microsurgery and/ or radiotherapy and new somatostatin analogues ${ }^{22}$. It is well known that $84 \%$ of prolactinomas express somatostatin receptors (SSTR) type 1 (SSTR1), $63 \%$ express SSTR 2 and $71 \%$ express SSTR5 ${ }^{23,24}$. It was recently demonstrated that somatostatin analogues, preferential for the SSTR5 receptor subtype, suppress PRL release in prolactinoma cell cultures by $30-40 \%{ }^{24}$. These data supported the idea of somatostatin receptor subtype-specific control of PRL secretion in such tumours, and were found to produce a significant inhibition of PRL release ${ }^{24}$. Multiligand analogues have also been tried and proved to inhibit PRL release by both mixed GH/PRL adenomas and pure prolactinomas in vitro ${ }^{25-27}$

Recently a new somatostatin-dopamine hybrid molecule was introduced with potentially functional synergy on GH and PRL release ${ }^{28}$. This molecule most likely constitutes a new therapeutic approach for mixed GH/PRL adenomas and possibly for resistant prolactinomas.

The usefulness of antiestrogen therapy in prolactinomas is controversial. It is known that prolactinomas express nuclear estrogen receptors at higher concentrations than other pituitary adenomas ${ }^{29,30}$. In one study with 29 patients suffering from prolactinomas, it was shown that variables such as gender, age, menstrual status, exposure to dopamine agonists, PRL levels or tumour size were not predictive for the presence of estrogen receptors in prolactinomas $^{31}$. Caronti et $\mathrm{al}^{32}$ showed that tamoxifen has an inhibitory effect on cell proliferation of human pituitary adenomas, independently of estrogen receptor expression. Rat models to study the effects of antiestrogens on pituitary ${ }^{33}$ are valuable for investigation of such treatment in human pituitary adenomas.

In conclusion, we describe a patient with a prolactinoma resistant to dopamine agonists and probable resistance of the mecolimbic dopaminergic system to dopamine agonists. 


\section{REFERENCES}

1. Molitch ME, 1999 Medical treatment of prolactinomas. Endocrinol Metab Clin North Am 28: 143-169.

2. Colao A, di Sarno A, Pivonello R, di Somma C, Lombardi G, 2002 Dopamine receptor agonists for treating prolactinomas. Expert Opin Investig Drugs 11: 787800.

3. Brue T, Pellegrini I, Priou A, Morange I, Jaqurt P, 1992 Prolactinomas and resistance to dopamine agonists. Horm Res 38: 84-89.

4. Rohmer V, Freneau E, Morange I, Simonetta C, 2000 Efficacy of quinagolide in resistance to dopamine agonists: results of a multicenter study. Club de l' Hypophyse. Ann Endocrinol 61: 411-417.

5. Cone RD, Low MJ, Elmquist JK, Cameron JL 2003 Neuroendocrinology. In: Larsen PR, Kronenberg HM, Melmed S, Polonsky KS Saunders (ed) Williams Textbook of Endocrinology, Elsevier Science, United States of America; pp, 95-98

6. Mukhergee J, Narayanan TK, Christian BT, Shi B, Yang ZX, 2004 Binding characteristics of high affinity dopamine D2/D3 receptor agonists, 11C-PPHT and $11 \mathrm{C}-\mathrm{ZYY}-39$ in rodents and imaging in non-human primates by PET. Synapse 54: 83-91.

7. Olsson H, Halldin C, Farde L, 2004 Differentiation of extrastriatal dopamine D2 receptor density and affinity in the human brain using PET. Neuroimage 22: 794803.

8. Gardner DG, Nissenson RA 2004 Mechanisms of hormone action. In: Greenspan FS, Gardner DG Basic and Clinical Endocrinology The McGraw-Hill Companies, Inc, United States of America; pp, 65-66.

9. Molitch ME, 2003 Dopamine resistance of prolactinomas. Pituitary 6: 19-27.

10. Caccavelli L, Cussac D, Pellegrini I, Audinot V, Jaquet P, Enjalbert A, 1992 D2 dopaminergic receptors: normal and abnormal transduction mechanisms. Horm Res 38: 78-83.

11. Pellegrini I, Rasolonjanahary R, Gunz G, et al, 1989 Resistance to bromocriptine In prolactinomas J Clin Endocrinol Metab Sep 69: 500-509.

12. Caccavelli L, Feron F, Morange I, et al, 1994 Decreased expression of the two D2 dopamine receptor isoforms in bromocriptine-resistant prolactinomas Neuroendocrinology Sep 60: 314-322.

13. Barlier A, Pellegrini-Bouiller I, Caccavelli L, et al, 1997 Abnormal transduction mechanisms in pituitary adenomas. Horm Res 47: 227-234.

14. Collu R, Bouvier C, Lagace G, et al, 1988 Selective deficiency of guanine nucleotide-binding protein Go in two dopamine-resistant pituitary tumors. Endocrinology Mar 122: 1176-1178.

15. Roberts DJ, Lin H, Strange PG, 2004 Mechanisms of agonist action at D2 Dopamine receptors Mol Pharmacol Aug 31 [Epub ahead of print].
16. Barlier A, Pellegrini-Bouiller I, Gunz G, Jaquet P, Enjalbert A, 1997 Homeoproteins and pituitary adenoma. Ann Endocrinol 58: 3-10.

17. Essential Psychopharmacology

18. Luchsinger A, Velasco M, Urbina A, et al, 1992 Comparative effects of dopaminergic agonists on cardiovascular, renal and rennin-angiotensin systems in hypertensive patients. J Clin Pharmacol Jan 32: 55-60.

19. Luchsinger A, Grilli M, Velasco M, 1998 Metoclopramide and domperidone block the antihypertensive effect of bromocriptine in hypertensive patients. Am J Ther 5: 81-88.

20. Boyd A, 1995 Bromocriptine and psychosis: a literature review. Psychiatr Q Spring 66: 87-95.

21. Peter SA, Autz A, Jean-Simon ML, 1993 Bromocriptine-induced schizophrenia. J Natl Med Assoc Sep 85: 700-701.

22. Shimon I, Yan X, Taylor JE, Weiss MH, Culler MD, Melmed S, 1997 Somatostatin receptor (SSTR) subtype-selective analogues differentially suppress in vitro growth hormone and prolactin in human pituitary adenomas. Novel potential therapy for functional pituitary tumors. J Clin Invest 1 100: 2386-2392.

23. Hofland LJ, Lamberts SW, 2004 Somatostatin receptors in pituitary function, diagnosis and therapy. Front Horm Res 32: 235-252.

24. Jaquet P, Ouafik L, Saveanu A, et al, 1999 Quantitative and functional expression of somatostatin receptor subtypes in human prolactinomas. J Clin Endocrinol Metab 84: 3268-3276.

25. Schmid HA, Schoeffter P, 2004 Functional activity of the multiligand analog SOM230 at human recombinant somatostatin receptor subtypes supports its usefulness in neuroendocrine tumours. Neuroendocrinology 80 (Suppl 1): 47-50.

26. Hofland LJ, van der Hoek J, van Koetsveld PM et al, 2004 The novel somatostatin analog SOM230 is a potent inhibitor of hormone release by growth hormoneand prolactin-secreting pituitary adenomas. J Clin Endocrinol Metab 89: 1577-1585.

27. Shimon I, Rubinek T, Hadani M, Alhadef N, 2004 PTR-3173 (somatoprim), a novel somatostatin analog with affinity for receptors 2,4 and 5 is a potent inhibitor of human GH secretion. J Endocrinol Invest 27: 721-727.

28. Shimon I, 2003 Somatostatin receptors in pituitary and development of somatostatin receptor subtype-selective analogs. Endocrine 20: 265-269.

29. Badichev VN, Marova EI, Kuznetsova TA, 2001 Role of sex hormones in development of pituitary adenomas. Bull Exp Biol Med 131: 309-311.

30. Shupnik MA, Pitt LK, Soh AY, Anderson A, Lopes MB, Laws Er Jr, 1998 Selective expression of estrogen receptors alpha and beta isophorms in human pituitary tumors. J Clin Endocrinol Metab 83: 3965-3972.

31. Kaptain GJ, Simmons NE, Alden TP, Lopes MB, 
Vance ML, Laws ER, 1999 Estrogen receptors in prolactinomas: a clinico-pathological study. Pituitary 1: 9198.

32. Caronti B, Palladini G, Bevilacqua MG, et al, 1993 Effects of 17 beta-estradiol, progesterone and tamoxifen on in vitro proliferation of human pituitary ade- nomas: correlation with specific cellular receptors. Tumour Biol 14: 59-68.

33. Leung G, Tsao SW, Wong YC, 2002 The effect of flutamide and tamoxifen on sex hormone induced mammary carcinogenesis and pituitary adenoma. Breast Cancer Res Treat 72: 153-162. 